\title{
Utilisation of rapeseed protein isolates for production of peptides with angiotensin l-converting enzyme (ACE)-inhibitory activity
}

\author{
Por Justo Pedroche, María M. Yust, Cristina Megías, Hassane Lqari, Manuel Alaiz, \\ Julio Girón-Calle, Francisco Millán and Javier Vioque*
}

\author{
Departamento de Fisiología y Tecnología de Productos Vegetales. Instituto de la Grasa (CSIC). \\ Avda. Padre García Tejero n4,41012, Sevilla,Spain.E-mail:jvioque@cica.es
}

\section{RESUMEN}

Utilización de aislados proteicos de colza para la producción de péptidos con actividad inhibidora de la enzima convertidora de la angiotensina (ECA).

La actividad de ECA está relacionada con una presión arterial alta y enfermedades cardíacas. Un aislado proteico de colza se hidrolizó con alcalasa para estudiar la posible presencia de péptidos inhibidores de ECA en el hidrolizado. La hidrólisis durante 30 min produjo el hidrolizado con la mayor actividad inhibidora de ECA. Dos fracciones de este hidrolizado, obtenidas por cromatografía de filtración en gel Biogel P2, se usaron para la purificación de péptidos inhibidores de ECA. Tres fracciones con actividad inhibidora de ECA se purificaron mediante HPLC en fase reversa de las fracciones obtenidas mediante Biogel P2. Esto demuestra que los hidrolizados proteicos de colza representan una buena fuente de péptidos inhibidores de ECA.

PALABRAS-CLAVE: Aislado proteico - Colza - Enzima convertidora de angiotensina - Hidrolizado proteico - Péptidos inhibidores

\section{SUMMARY}

Utilisation of rapeseed protein isolates for production of peptides with angiotensin l-converting enzyme (ACE)inhibitory activity.

ACE activity is related to increased arterial pressure and coronary diseases. A rapeseed protein isolate was hydrolyzed with the protease Alcalase in order to investigate the possible presence of ACE inhibitory peptides in the resulting hydrolysates. Hydrolysis for $30 \mathrm{~min}$ yielded a hydrolysate with the highest ACE inhibitory activity. Two fractions of this hydrolysate obtained by Biogel P2 gel filtration chromatography were used for further purification of ACE inhibitory peptides. Three fractions with ACE inhibitory activity were purified by reverse-phase HPLC of Biogel P2 fractions. This demonstrates that rapeseed protein hydrolysates represent a good source of ACE inhibitory peptides.

KEY-WORDS: Angiotensin converting enzyme - Peptide inhibitors - Protein hydrolysate - Protein isolate - Rapeseed.

\section{INTRODUCTION}

Rapeseed is one of the most important oilseed crops cultivated in the world, ranking fourth with respect to oil production after soybean, palm, and cottonseed (FAO, 2002). The main producing countries are China, India and Canada, respectively. Rapeseed is rich in protein (between 30 and $45 \%$ ), and therefore defatted rapeseed meal may constitute a good source of protein for humans (Finlayson, 1976). Protein isolates obtained from defatted rapeseed meal, free of anti-nutritional components such as glucosinolates, phenols or phytic acid may be used for the fortification of foods (Dev and Mukherjee, 1986; Zhou et al., 1990). Rapeseed protein hydrolysates have been obtained with different proteases, such as Alcalase, Pronase, or Neutrase (Kim et al., 1992a,b) in order to improve the functional properties of the original proteins (Vioque et al., 2000a). Extensive hydrolysates to be used as food supplements or in special medical diets have been obtained as well (Vioque et al., 1999).

In recent years, protein hydrolysates are also considered a source of bioactive peptides. These are short-chain peptides, produced by enzymatic hydrolysis, that can be absorbed by intestinal enterocytes and reach the blood stream leading to a biological activity that may be beneficial (Vioque et al., 2000b). Bioactive peptides with different activities have been described, including immunomodulatory, antimicrobial, antithrombotic and antihypertensive activities (Clare and Swaisgood, 2000).

Antihypertensive peptides inhibit the angiotensin-converting enzyme (ACE). This enzyme hydrolyzes the decapeptide angiotensin I to yield the vasoconstrictor octapeptide angiotensin II, and in addition hydrolyzes the vasodilator peptide bradikinin. Angiotensin II is involved in the release of aldosterone, a sodium-retaining steroid, which increases blood pressure. Thus, the activity of ACE increases blood pressure by raising vascular resistance and fluid volume. High blood pressure is associated with a higher risk of cardiovascular disease and stroke. ACE inhibitors are used in the treatment of hypertension and have been studied for the treatment of chronic heart failure and myocardial infarction (Pitt, 1997).

ACE peptide inhibitors have been purified from several foodstuffs: casein, whey, cheese, gelatine, fish, wheat, corn, chickpea or even mushrooms (Yamamoto, 1997). Alcalase has been used for the preparation of ACE peptide inhibitors from protein of 
different sources, such as bovine proteins (Hyun and Shin, 2000; Kim et al., 2001), fish (Byun and Kim, 2001; Matsufuji et al., 1993; 1994), wheat (Matsui et al., 1999; 2000), soy (Wu and Ding, 2002), and chickpea (Pedroche et al., 2002) proteins.

The goal of this paper was to determine their presence and to purify ACE-inhibitory peptides in defatted rapeseed meal protein hydrolysates produced by treatment with the protease Alcalase.

\section{MATERIALS AND METHODS}

\section{Materials}

Hippuryl-L-histidyl-L-leucine (HHL), Captopril, 2,4,6trichloro-s-triazine (TT), trinitrobenzenesulphonic acid (TNBS) and phenylmethylsulfonyl fluoride (PMSF) were purchased from Sigma. All other chemicals were of analytical grade.

Rapeseed seeds were a gift from Koipesol Semillas S.A. (Sevilla, Spain). The seeds were ground and extracted with hexane in a soxhlet extractor for $9 \mathrm{~h}$ to remove most of the fat. The resulting defatted rapeseed flour was used as the starting material for the production of protein hydrolysates.

\section{Proteolytic enzymes}

The enzyme used was Alcalase $2.4 \mathrm{~L}$ (Novo Nordisk, Bagsvaerd, Denmark). Alcalase $2.4 \mathrm{~L}$ is a microbial protease preparation with endopeptidase activity produced by Bacillus licheniformis. A main component of the commercial preparation is the serine protease subtilisin $A$. The specific activity of Alcalase $2.4 \mathrm{~L}$ is 2.4 Anson Unit (AU)/g.

\section{Protein determination}

Protein amounts were determined by elemental analysis using a LECO CHNS-932 analyzer (St. Joseph, MI), and were calculated as percentage nitrogen content $\times 6.25$.

\section{Preparation of angiotensin-converting enzyme}

Angiotensin-converting enzyme was prepared according to Hayakari et al. (1978) with modifications. Pig lungs purchased in a local market were used as starting material. Tissue samples were diced and homogenized in 10 volumes of ice-cold 10 $\mathrm{mM}$ potassium phosphate buffer, $\mathrm{pH} 8.3$, containing $0.25 \mathrm{M}$ sucrose and $0.1 \mathrm{mM}$ PMSF. The homogenate was centrifuged at $5000 \mathrm{~g}$ for 10 minutes, and the resulting supernatant was dialyzed for 24 hours against 20 volumes of the same buffer at $4{ }^{\circ} \mathrm{C}$. The buffer was renewed four times. The dialyzed was used as the source of ACE. In order to verify the absence of undesirable proteases such as carboxypeptidase in ACE extracts, the kinetics of $\mathrm{HHL}$ hydrolysis by ACE was followed in the presence or absence of captopril, a potent ACE inhibitor. This assay demonstrated that hydrolysis was due to ACE and not to other proteases, since hydrolysis of $\mathrm{HHL}$ in the presence of captopril was residual and similar to the hydrolysis of the substrate alone (data not shown).

\section{Assay of angiotensin-converting enzyme}

Angiotensin-converting enzyme activity was determined according to Hayakari et al. (1978) with modifications. This method relies on the colorimetric reaction of hippuric acid with TT, developed in a 0.5 $\mathrm{ml}$ incubation mixture containing a $40 \mu \mathrm{mol}$ potassium phosphate buffer, $\mathrm{pH} 8.3,300 \mu \mathrm{mol}$ sodium chloride, $1.5 \mu \mathrm{mol}$ of $\mathrm{HHL}$, and $1 \mu \mathrm{g}$ of enzyme extract. Incubation was carried out for 15 minutes at $37^{\circ} \mathrm{C}$. The reaction was terminated by the addition of $1.5 \mathrm{ml} 3 \%$ TT in dioxane, followed by $3 \mathrm{ml}$ of $0.2 \mathrm{M}$ phosphate buffer, $\mathrm{pH}$ 8.3. After the reaction mixtures were centrifuged at $10000 \mathrm{~g}$ for $10 \mathrm{~min}$, the product of the reaction was determined in the supernatant by measuring its absorbance at $382 \mathrm{~nm}$.

\section{Preparation of protein isolate}

Defatted rapeseed flour $(20 \mathrm{~g})$ was suspended in $200 \mathrm{ml}$ of $0.2 \% \mathrm{NaOH}$ solution, $\mathrm{pH} 12$, and extracted by stirring for 1 hour. After centrifugation at $8000 \mathrm{~g}$ for $20 \mathrm{~min}$, two additional extractions of the pellet were carried out with half the volume of alkaline solution. The three supernatants were pooled and the $\mathrm{pH}$ adjusted to the isoelectric point $(\mathrm{pH} 4.3)$ and the precipitate formed was recovered by centrifugation as described above. The precipitate was washed with distilled water adjusted to $\mathrm{pH} 4.3$ and freeze-dried until further use.

\section{Hydrolysis}

Protein isolates were hydrolyzed in batches by treatment with Alcalase in a pH-stat for 60 minutes. The protein isolate was suspended in water and the $\mathrm{pH}$ adjusted to 8 . A hydrolysis curve was obtained by the $\mathrm{pH}$-stat technique using the following hydrolysis parameters: substrate concentration, $10 \%$; enzyme/ substrate ratio, $0.3 \mathrm{AU} / \mathrm{g}, \mathrm{pH} 8$, and temperature 50 ${ }^{\circ} \mathrm{C}$. Hydrolysis was conducted in a $1000 \mathrm{ml}$ reaction vessel equipped with a stirrer, thermometer and $\mathrm{pH}$ electrode. Aliquots $(50 \mathrm{ml})$ were withdrawn at $10 \mathrm{~min}$, $30 \mathrm{~min}$ and $60 \mathrm{~min}$. Hydrolysis was stopped by acidification to $\mathrm{pH} 5$. Hydrolysates were clarified by ultrafiltration through $0.45 \mathrm{~nm}$ filters to remove insoluble substrate and residual enzymes. Filtrates were lyophilized for storage at $-20^{\circ} \mathrm{C}$. 


\section{Degree of hydrolysis}

The degree of hydrolysis was calculated by the determination of free amino groups by reaction with TNBS (Adler-Nissen, 1979). The total number of amino groups was determined in a sample $100 \%$ hydrolyzed by incubation with $6 \mathrm{~N} \mathrm{HCl}$ at $120^{\circ} \mathrm{C}$ for 24 hours.

\section{Biogel P2 chromatography}

Rapeseed protein hydrolysates $(10 \mathrm{mg}$ in $50 \mathrm{mM}$ ammonium bicarbonate) were injected into a Biogel P2 (BIO-RAD) gel filtration column $(2 \times 55 \mathrm{~cm})$ at a flow rate of $10 \mathrm{ml} / \mathrm{h}, 50 \mathrm{mM}$ ammonium bicarbonate. Fractions selected for further purification of peptides were pooled and taken to dryness before HPLC $\mathrm{C}_{18}$ chromatography. Peptide molecular masses were determined using cytochrome C (12384 Da), bacitracin $(1400 \mathrm{Da}), \mathrm{Val}^{4}$-angiotensin $(917 \mathrm{Da})$, Arg-Lys-Glu-Val-Tyr (693 Da) and Trp-Gly (261 Da) as molecular weight standards.

\section{HPLC $\mathrm{C}_{18}$ chromatography}

Fractions collected from Biogel P2 chromatography were re-dissolved in water and injected in an HPLC reverse-phase column $\left(\mathrm{C}_{18}\right.$ Hi-Pore RP-318, 250 x 10 BIO-RAD column). Elution was achieved through a linear gradient of acetonitrile ( 0 to $30 \%$ for $60 \mathrm{~min}$ ) containing $0.1 \%$ trifluoroacetic acid at a flow rate of $4 \mathrm{ml} / \mathrm{min}$ at $30^{\circ} \mathrm{C}$. Elution was monitored at $214 \mathrm{~nm}$ and individual peaks were collected for (assay) trials of ACE inhibitory activity.

\section{RESULTS AND DISCUSSION}

In general, ACE inhibitory peptides have been obtained from food proteins by hydrolysis using

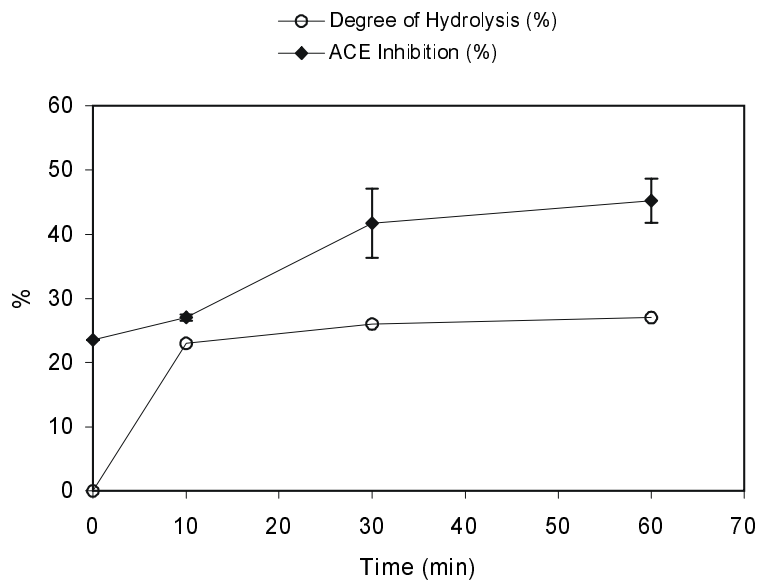

Figure 1

Time course of the hydrolysis of rapeseed protein isolate by Alcalase and ACE inhibitory activity of the resulting hydrolysates (data corresponding to duplicate determinations and the corresponding average are shown). digestive enzymes, such as pepsin, pancreatin, trypsin or chymotripsin. More recently, microbial enzymes such as Alcalase (see Introduction) or flavourzyme (Pedroche et al., 2002; Janitha et al., 2002) have been employed in the generation of antihypertensive peptides.

A rapeseed protein isolate obtained from defatted rapeseed meal by alkaline extraction and isoelectric precipitation was used as a substrate for the generation of the protein hydrolysate. This protein isolate, with more than $95 \%$ protein content, is a good starting material for hydrolysis. Alcalase is a non-specific commercial endoprotease preparation that has been used in our laboratory for the preparation of extensive protein hydrolysates from rapeseed (Vioque et al., 1999), sunflower (Villanueva et al., 1999) and chickpea (Clemente et al., 1999). These previous studies showed that treatment with Alcalase for less than 30 minutes is usually enough to reach the maximum degree of hydrolysis. The rapeseed isolates used for the present work were hydrolyzed for up to 1 hour (Figure 1). The original isolate already presented an ACE inhibitory activity of $23 \%$, which was approximately doubled by the proteolytic treatment. The degree of hydrolysis hardly increased after 10 minutes of treatment with Alcalase, although ACE inhibitory activity kept increasing after that time. This most likely highlights the fact that after a certain point, the hydrolysis of relatively few peptidic bonds may be critical for the generation of bioactive peptides.

Since treatment with Alcalase for more than 30 minutes did not substantially increase the ACE inhibitory activity, which is consistent with previous work in which the maximum inhibition of ACE was achieved after 30 minutes of hydrolysis of chickpea proteins (Pedroche et al., 2002), the hydrolysate obtained after 30 minutes of hydrolysis was used in attempt to purify the ACE inhibitory peptides.

After centrifugation and filtration through 0.45 $\% \mathrm{~m}$, the 30-minute Alcalase hydrolysate was applied

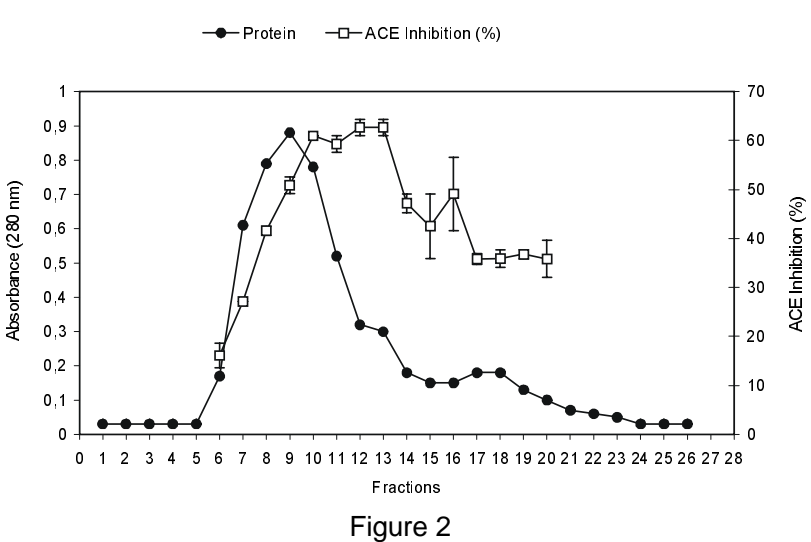

Biogel P2 gel filtration chromatography of 30 minutes rapeseed protein hydrolysate and ACE inhibitory activity of the fractions collected (data corresponding to duplicate determinations and the corresponding average are shown). 
to a Biogel P2 gel filtration column (Figure 2). Fractions 6 to 20 were tested for ACE inhibitory activity. Fractions 12 and 13, corresponding to a shoulder in the protein elution profile, gave the highest ACE inhibition, and were selected for further purification of peptide inhibitors. These fractions have an elution volume that corresponds to $1500 \mathrm{Da}$ apparent molecular weight. This would correspond to peptides with 12-13 residues as an average. Although this size is higher than the usual size reported for ACE inhibitory peptides, peptides of this size possessing ACE inhibitory activity have been purified from casein (Maruyama and Suzuki, 1982).

Pooled fractions 12 and 13 selected from the Biogel P2 column were loaded on a HPLC $C_{18}$ reverse phase column for further purification of peptides. The elution profile is shown in Figure 3. Peptides were collected in four fractions and tested for ACE-inhibitory activity (Figure 4). Peptides belonging to the fraction with the longest retention time, between 37.5 and $49 \mathrm{~min}$, possessed the highest inhibitory activity. This was an expected result, since ACE inhibitory peptides are usually

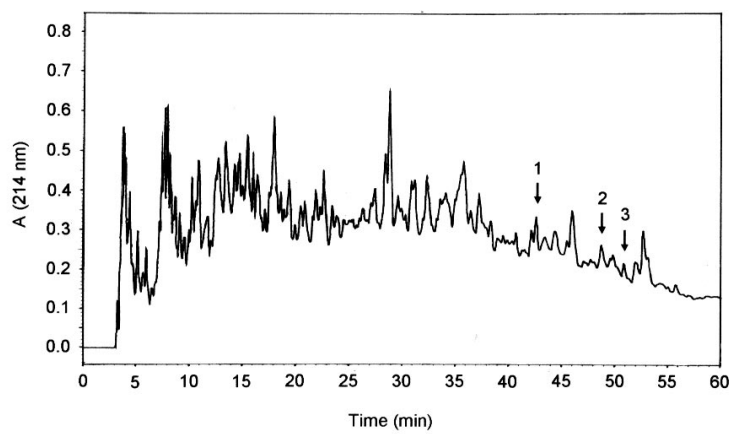

Figure 3

HPLC $\mathrm{C}_{18}$ reverse phase column chromatography of pooled fractions 12 and 13 purified by Biogel P2 gel filtration chromatography (see Figure 2). Fractions with ACE inhibitory activity are indicated with an arrow.

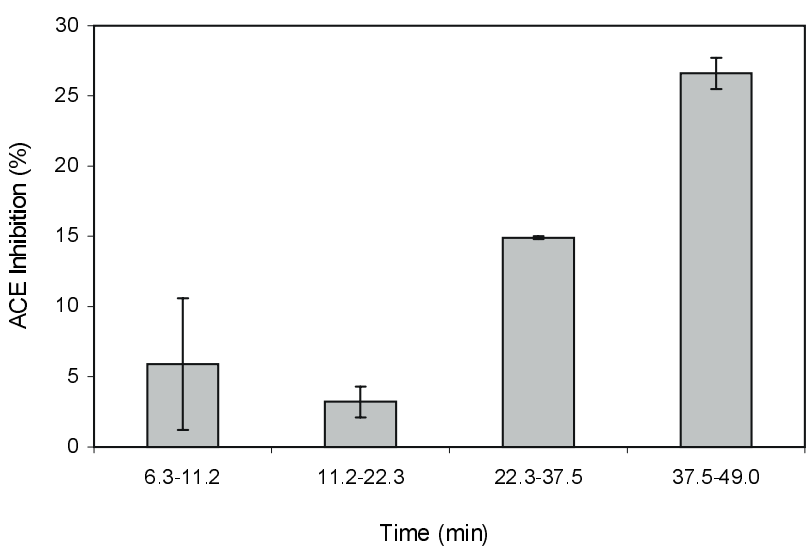

Figure 4

ACE inhibitory activity in fractions obtained by HPLC $\mathrm{C}_{18}$ reverse phase chromatography (data corresponding to duplicate determinations and the corresponding average are shown).

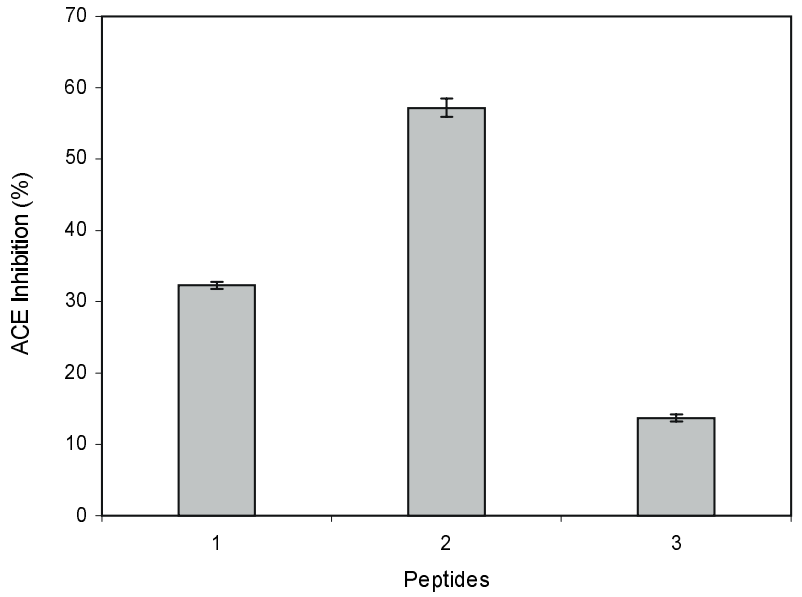

Figure 5

ACE inhibitory activity of fractions purified by HPLC $\mathrm{C}_{18}$ reverse phase column chromatography (results are the mean \pm SD of three determinations).

constituted by hydrophobic amino acids that increase the interaction of peptides with the column and delay elution. A similar pattern has also been observed during the purification of chickpea ACE inhibitory peptides (Pedroche et al., 2002).

Individual peaks collected from this fraction were tested for ACE inhibitory activity (Figure 5). Three peaks were inhibitory for ACE, demonstrating the generation of ACE inhibitory peptides after rapeseed protein isolate hydrolysis. Therefore, rapeseed proteins may represent a source of bioactive peptides after modification by food-grade microbial enzymes. It remains to be determined whether these peptides are resistant to hydrolysis by digestive enzymes, and whether they can be absorbed by enterocytes and be incorporated into the bloodstream.

These results point out the possibility of obtaining bioactive peptides from rapeseed proteins by means of a controlled protein hydrolysis using a microbial protease, allowing the generation of a functional food product with possible applications in specific diets. The low cost of the protease and substrate represent the revalorization of an agricultural waste, defatted rapeseed meal that may be transformed into a highly valuable additive (added value) such as hypotensive protein hydrolysates.

\section{ACKNOWLEDGEMENTS}

This work was supported by research grant AGL 2001-0526 (F.M.), AGL 2002-02836 (J.G.C.) and a Ramón y Cajal contract (J.G.C.).

\section{REFERENCES}

Adler-Nissen, J. 1979. Determination of the degree of hydrolysis of food protein hydrolysates by trinitrobenzenesulfonic acid. J. Agric. Food Chem. 27, 1256-1262. 
Byun H.G., Kim S.K. 2001. Purification and characterization of angiotensin I converting enzyme (ACE) inhibitory peptides from Alaska pollack (Theragra chalcogramma) skin. Proc. Biochem. 36, 1155-1162.

Clare, D.A., Swaisgood, H.E. 2000. Bioactive milk peptides: a prospectus. J. Dairy Sci. 83, 1187-1195.

Clemente, A., Vioque, J., Sánchez-Vioque, R., Pedroche, J., Bautista, J., Millán, F. 1999. Protein quality of chickpea (Cicer arietinum L.) protein hydrolysates. Food Chem. 67, 269-274.

Dev, D.K., Mukherjee, K.D. 1986. Functional properties of rapeseed protein products with varying phytic acid contents. J. Agric. Food Chem. 34, 775-780.

FAO/WHO/UNU. 2002. Agricultural bulletin board on data collection, dissemination and quality of statistics. Geneva: World Health Organization.

Finlayson, A.J. 1976. The Seed Protein Contents of some Cruciferae, in The Biology and Chemistry of the Cruciferae, edited by J.G. Vaughan, A.J. McLeod, and B.M.G. Jones, Academic Press, London.

Hayakari, M., Kondo, Y., Izumi, H., 1978. A rapid and simple spectrophotometric assay of angiotensin-converting enzyme. Anal. Biochem. 84, 361-369.

Hyun C.K., Shin H.K. 2000. Utilization of bovine blood plasma proteins for the production of angiotensin I converting enzyme inhibitory peptides. Proc. Biochem. 36, 65-71.

Janitha, P.K., Wanasundara, P.D., Ross, A.R.S., Amarowicz, R., Ambrose, S.J., Pegg, R.B., Shand, P.J. 2002. Peptides with angiotensin I-converting enzyme (ACE) inhibitory activity from defibrinated, hydrolyzed bovine plasma. J. Agric. Food Chem. 50, 6981-6988.

Kim, C.H., Kim, H.S., Jung, Y.H., Kang, Y.J. 1992a. Conditions for hydrolysis of rapeseed proteins by pronase. J. Korean Soc. Food Nutr. 21, 513-518.

Kim, C.H., Kim, H.S., Lee, J.S., Kang, Y.J. $1992 b$. Functionality changes of rapeseed protein upon proteolysis. J. Korean Soc. Food Nutr. 21, 519-524.

Kim S.K., Byun H.G., Park P.J., Shahidi F. 2001. Angiotensin I converting enzyme inhibitory peptides purified from bovine skin gelatin hydrolysate. J. Agric. Food Chem. 49, 2992-2997.

Maruyama, S., Suzuki, H. 1982. A peptide inhibitor of angiotensin-I converting enzyme in the tryptic hydrolysate of casein. Agric. Biol. Chem. 46, 1393-1394.

Matsui, T., Li, C.H., Osajima, Y. 1999. Preparation and characterization of novel bioactive peptides responsible for angiotensin l-converting enzyme inhibition from wheat germ. J. Peptide Sci. 5, 289-297.
Matsui T, Li C.H., Tanaka T., Maki T., Osajima Y., Matsumoto K. 2000. Depressor effect of wheat germ hydrolysate and its novel angiotensin I-converting enzyme inhibitory peptide, lle-Val-Tyr, and the metabolism in rat and human plasma. Biol. Pharmac. Bull. 23, 427-431.

Matsui, T., Matsufuji, H., Seki, E., Osajima, K., Nakashima, M., Osajima, Y. 1993. Inhibition of Angiotensin I-converting enzyme by Bacillus licheniformis alkaline protease hydrolysates derived from sardine muscle. Biosc. Biotech. Biochem. 57, 922-925.

Matsufuji, H., Matsui, T., Seki, E., Osajima, K., Nakashima, M., Osajima, Y. 1994. Angiotensin I-converting enzyme inhibitory peptides in an alkaline protease hydrolysate derived from sardine muscle. Biosc. Biotech. Biochem. 58, 2244-2245.

Pedroche, J., Yust, M.M., Girón-Calle, J., Alaiz, M., Millán, F., Vioque, J. 2002. Utilisation of chickpea protein isolates for production of peptides with angiotensin I-converting enzyme (ACE)-inhibitory activity. J. Sci. Food Agric. 82, 960-965.

Pitt, B. 1997. ACE inhibitors in heart failure: prospects and limitations. Cardiovasc. Drug Ther. 11, 285-290.

Villanueva, A., Vioque, J., Sánchez-Vioque, R., Clemente, A., Pedroche, J., Bautista, J., Millán, F. 1999. Peptide characteristics of sunflower protein hydrolysates. $J$. Am. Oil Chem. Soc. 76, 1455-1460.

Vioque, J., Sánchez-Vioque, R., Clemente, A., Pedroche, J., Bautista, J., Millán, F. 1999. Production and characterization of an extensive rapeseed protein hydrolysate. J. Am. Oil Chem. Soc. 76, 819-823.

Vioque, J., Sánchez-Vioque, R., Clemente, A., Pedroche, J., Millán, F. 2000a. Partially hydrolyzed rapeseed protein isolates with improved functional properties. $J$. Am. Oil Chem. Soc. 77, 447-450.

Vioque, J., Sánchez-Vioque, R., Clemente, A., Pedroche, J., Yust, M.M., Millán, F. 2000b. Bioactive peptides in storage proteins. Grasas y Aceites 51, 361-365.

Wu, J., Ding, X. 2002. Characterization of inhibition and stability of soy-protein-derived angiotensin l-converting enzyme inhibitory peptides. Food Res. Inter. 35, 367-375.

Yamamoto, N. 1997. Antihypertensive peptides derived from food proteins. Biopolymers 43, 129-134.

Zhou, B., He, Z.Q., Yu, H.M., Mukherjee, K.D. 1990. Proteins from double-zero rapeseed. J. Agric. Food Chem. 38, 690-694. 